\title{
Yield Losses Associated with Virus-Infected Garlic Plants During Five Successive Years
}

\author{
Vilma C. Conci, Ana Canavelli, and P. Lunello, Instituto de Fitopatología y Fisiología Vegetal INTA, Camino 60 \\ Cuadras km 5 y 1/2, (5119), Córdoba, Argentina; J. Di Rienzo, Facultad de Ciencias Agropecuarias, Universidad \\ Nacional de Córdoba, Av. Valparaiso s/n Ciudad Universitaria, Córdoba, Argentina; S. F. Nome, Instituto de Fitopa- \\ tología y Fisiología Vegetal INTA, Camino 60 Cuadras km 5 y 1/2, (5119), Córdoba, Argentina; G. Zumelzu, Fac- \\ ultad de Ciencias Agropecuarias, Universidad Nacional de Córdoba, Av. Valparaiso s/n Ciudad Universitaria, Cór- \\ doba, Argentina; Rusell Italia, Agencia de Extensión Rural INTA Jesús María, Tucumán 255 (5220) Jesús María, \\ Córdoba, Argentina
}

\begin{abstract}
Conci, V. C., Canavelli, A., Lunello, P., Di Rienzo, J., Nome, S. F., Zumelzu, G., and Italia, R. 2003. Yield losses associated with virus-infected garlic plants during five successive years. Plant Dis. 87:1411-1415.

Virus-free garlic plants, when planted in the field, are quickly infected by viruses, but it is not known to what extent this affects the yield over successive crop cycles. The yield loss curve was studied for these plants during 5 years of tests in the field. Highly significant differences were detected in the weight and perimeter of bulbs in relation to the years of exposure to virus infection. An increase was observed in yield compared with chronically diseased plants of between 66 and $216 \%$ in weight and 13 and $37 \%$ in perimeter of bulbs in the first crop cycle and $49 \%$ in weight and $16 \%$ in perimeter in the fifth year. These results showed a gradual loss in yield until the third year, and subsequently the production values remained steady for the fourth and fifth years of testing but were still higher than those reached by chronically diseased plants.
\end{abstract}

Additional keywords: Allexivirus, Carlavirus, Leek yellow stripe virus, Onion yellow dwarf virus, virus complex, virus-free garlic plants

Garlic is infected by many viruses that produce chronic infections. The exclusively agamic propagation of garlic results in all garlic plants being infected by a large number of viruses, including aphid-borne Potyviruses (Onion yellow dwarf virus, OYDV, and Leek yellow stripe virus, LYSV) and Carlaviruses (Garlic common latent virus, GCLV, and Shallot latent virus, SLV) and mite-borne Allexiviruses (Garlic virus A, B, C, and D, GarV-A, B, C, and D) $(1,6,20,22-26,28)$.

Obtaining virus-free garlic plants involves high costs and considerable production time. The most commonly used method is meristem culture, which may or may not include a prior period of heat treatment, with the aim of increasing the possibilities of extracting a virus-free explant $(12,19,30)$. When an in vitro plant has finally been obtained, it is necessary to make rigorous analyses to establish if it is virus-free. Plants that are infected after meristem culture must be eliminated, and

Corresponding author: Vilma C. Conci

E-mail: vconci@correo.inta.gov.ar

Accepted for publication 12 June 2003.

Publication no. D-2003-0922-03R

(C) 2003 The American Phytopathological Society this often means the loss of many plants obtained in vitro $(9,12,19,27,30)$. The major problem in transplanting in vitro plant to the soil is dehydration, resulting in the death of many plants. After the plants have been established in the soil and have adapted to natural conditions, it is necessary to repeat the indexing to check for infection. In a program of production of virus-free plants, the analyses must be repeated several times throughout the vegetative cycle, since the distribution and concentration of virus may vary during this period. In this way, plants that at first test as virus-free may later be found to be infected $(9,11)$. Once the virus-free plants have been obtained, they are increased in cages or in areas isolated from virusinfected garlic crops until a sufficient number have been obtained to deliver to farmers. The complete procedure to get virus-free garlic plants involves at least 5 years. When planted commercially, their yields are higher than those of diseased plants, which can have reduction of bulb weight up to $60 \%(3,9,15,29)$.

Nonetheless, the garlic plants are quickly infected by viruses when grown in natural crop conditions. Between 87 and $100 \%$ of plants were infected with OYDV and between 62 and $87 \%$ with LYSV when they were planted close to other infected plants (9).
Infection rates differ with virus and vicinity to infected crops. Fields planted with virus-free bulbs show viral infection between 0 and $70 \%$ (for fields located near commercial crops) after 3 to 5 years. Plants are mainly infected by Potyvirus (21).

The aim of this work was to determine the curve of yield reduction in healthy, virus-free plants sown in the field, without protection, during five successive years.

\section{MATERIALS AND METHODS}

Serological techniques used and antisera. Virus infection was assessed using the double-antibody sandwich enzyme-linked immunosorbent assay (DAS-ELISA) (7). Immunosorbent electron microscopy plus decoration (ISEM-D) was also used for selecting the virus-free plants (17).

Antisera to OYDV, LYSV, GarV-A, and an antiserum obtained from garlic plants infected with the mix of viruses that naturally affect garlic (Mix-antiserum) were used, taken from the stock of IFFIVEINTA, and obtained as described $(10,13,14,16)$. Garlic yellow strike virus (GYSV) antiserum was kindly provided by M. Carvalho from UFV, Vicosa, Brazil, and R. Shepherd from the University of California, Davis $(4,5)$. Although this antiserum was obtained from a mixture of viruses, in previous work it was shown that it basically detects Allexivirus (V. C. Conci, unpublished results). OYDV antiserum was kindly provided by $\mathrm{H}$. Lot and B. Delecolle, INRA, Montfavet, France; LYSV and SLV by L. Bos and D. Maat, Research Institute for Plant Protection, Wageningen, The Netherlands; and antiserum to Carnation latent virus (CLV) by R. Milne and E. Luisoni from the Institute of Applied Plant Virology, Torino, Italy.

Plant material. Virus-free garlic plants cv. Blanco-IFFIVE were obtained by heat treatment followed by meristem culture (12) and analyzed by ISEM-D using OYDV, LYSV, GYSV, SLV, CLV, and Mix antisera. The plants were subjected to a hardening process and planted in the field in 1991 and increased during the following crop cycles under anti-aphid cages, to be used as healthy plants. The absence of 
virus infection in the plants was yearly verified by DAS-ELISA and ISEM-D.

Diseased controls were the same cultivar and were infected with the combination of viruses that naturally infects garlic.

Field assays. Five assays were performed between 1994 and 1998 to evaluate the yield loss in virus-free garlic plants sown in the field under natural infection conditions. The assays took place in the research field of the Instituto de Fitopatología y Fisiología Vegetal (IFFIVEINTA), in Córdoba, Argentina. In 1997, part of the assay was made in Montecristo (situated $18 \mathrm{~km}$ from Córdoba), and in 1998, blocks planted in Jesús María, Montecristo, and Río Primero (situated $48 \mathrm{~km}$ to the north, $24 \mathrm{~km}$ to the northeast, and 57 $\mathrm{km}$ to the east of Córdoba, respectively) were used.

Three days prior to planting, the cloves were disinfected by $1 \mathrm{~h}$ immersion in a solution of $25 \mathrm{~g}$ of Captan (Ntrichloromethyl-thio-tetrahydrophthalimide), $15 \mathrm{~g}$ of Sumilex (procymidone $N-\left(3^{\prime}, 5^{\prime}-\right.$ dichlorophenyl)-1,2-dimethylcyclopropane1,2-dicarboximide), $15 \mathrm{~g}$ of Pentacloro (pentachloro-nitrobenzene), and $25 \mathrm{~g}$ of Benlate (benomyl methyl 1-butylcarbamoyl-2-benzimidazole carbamate) in 25 liters of water.

The size of cloves used in the assays was standardized using three sieves of 2 , 1.5 , and $1 \mathrm{~cm}^{2}$, respectively, resulting in four size categories. Cloves used were those retained by the second and third sieves (categories 2 and 3, respectively).

The cloves were planted in furrows 60 $\mathrm{cm}$ apart and at $15 \mathrm{~cm}$ intervals. The experimental plots for assay were irrigated every 7 to 10 days and fertilized with ammonium sulfate at $150 \mathrm{~kg} \mathrm{ha}^{-1}$ applied in three doses between June and July.

The trials were carried out as a split-plot design with whole-plots arranged in complete blocks. Factors were: clove size (two levels, corresponding to the two sizes of cloves planted, whole-plot) and crop cycle (subplot-treatment). The number of levels of this factor increased by one every year of the test period. Each experimental unit included 50 cloves.

Following harvest, bulbs were stored in a dry place at room temperature. The weight and perimeter of the bulbs were recorded 30 days after harvest, and the treatments were compared by ANOVA. When needed, Fisher's LSD multiple comparisons test (18) was applied. Statistical analysis was carried out with InfoStat statistical software.

Numbers of virus-infected plants were determined by DAS-ELISA with OYDV, LYSV, and GYSV antisera. In 1998, plants were also tested for GarV-A (Allexivirus). In the first year of assay (1994), two crop cycles were compared: virus-free garlic (1st cycle) and garlic plants with the viral complex (VC). The trial was replicated in four blocks. The cloves were planted on 11 April and harvested on 7 November.

In 1995, three crop cycles were contrasted: new cloves of virus-free garlic (1st cycle), cloves from plants planted virusfree in 1994 (2nd cycle), and VC. The trial was replicated in four blocks, planted on 5 April and the bulbs harvested on 23 November.

In 1996, four crop cycles were evaluated: cloves planted virus-free that year (1st cycle), cloves from the plants planted virus-free in 1995 (2nd cycle), cloves of garlic planted virus-free in 1994 (3rd cycle), and VC. The assay was replicated in four blocks. The trial was planted on 7 April and the bulbs were harvested on 20 November.

In 1997, five crop cycles were compared: garlic planted virus-free in 1997 (1st cycle), planted virus-free in 1996 (2nd cycle), planted virus-free in 1995 (3rd cycle), planted virus-free in 1994 (4th cycle), and VC. In 1997, two locations were used with four complete blocks in Córdoba (IFFIVE-INTA) and three blocks in Montecristo. The assay was planted on 16 April and harvested on 20 November.

In 1998, six crop cycles were evaluated: cloves of garlic planted virus-free in 1998

Table 1. Percentage of garlic plants infected by Onion yellow dwarf virus (OYDV), Leek yellow stripe virus (LYSV), Garlic virus A (GarV-A), and the mixture of viruses detected by Garlic yellow stripe virus (GYSV) antiserum during different years

\begin{tabular}{lcccc}
\hline \multirow{2}{*}{$\begin{array}{l}\text { Treatments } \\
\text { (year of assay) }\end{array}$} & GYSV & OYDV & LYSV & GarV-A \\
\cline { 2 - 5 } 1st Cycle (1994) & 76 & 42 & 62 & $\ldots$ \\
1st Cycle (1995) & 92 & 100 & 86 & $\ldots$ \\
1st Cycle (1996) & 99 & 99 & 80 & $\ldots$ \\
1st Cycle (1997) & 80 & 98 & 84 & $\ldots$ \\
1st Cycle (1998) & 56 & 97.5 & 54 & 7.5 \\
2nd Cycle (1996) & 100 & 66 & 91 & $\ldots$ \\
2nd Cycle (1997) & 100 & 100 & 90 & $\ldots$ \\
2nd Cycle (1998) & 82.5 & 95 & 55 & 15 \\
3rd Cycle (1997) & 100 & 100 & 96 & $\ldots$ \\
3rd Cycle (1998) & 100 & 100 & 74 & 12.5 \\
4th Cycle (1997) & 100 & 100 & 98 & $\ldots$ \\
4th Cycle (1998) & 100 & 99 & 92.5 & 14 \\
5th Cycle (1998) & 100 & 100 & 90 & 18 \\
VC (1997) & 100 & 100 & 100 & $\ldots$ \\
VC (1998) & 100 & 96 & 100 \\
\hline
\end{tabular}

(1st cycle), planted virus-free in 1997 (2nd cycle), planted virus-free in 1996 (3rd cycle), planted virus-free in 1995 (4th cycle), planted virus-free in 1994 (5th cycle), and VC. The trial was carried out in four different areas (Montecristo, Río Primero, IFFIVE-INTA, and Jesús María) with eight replicated complete blocks, two in each of the areas mentioned. The assay was planted on 27 March and harvested on 11 November in Montecristo and Río Primero, planted on 28 March and harvested on 10 November in IFFIVE-INTA, and planted on 31 March and harvested on 12 November in Jesús María.

The data collected for yield variables for the different number of crop cycles during the 5 years enabled the drawing of curves of decline in weight and perimeter. Average weight and perimeter for each crop cycle in every year were considered repetitions to draw the decline curve. The curve was fitted using the locally weighted regression smooth (8).

\section{RESULTS}

High percentages of virus infection were found in plants in the first year in the field (Table 1). Results varied by year and virus species. In the first crop cycle, infection with viruses detected with the GYSV antiserum was 56 to $99 \%$, with OYDV 42 to $100 \%$ and with LYSV 54 to $86 \%$. In the second crop cycle, values ranged between 82 and $100 \%$ for GVSV antiserum, 66 and $100 \%$ for OYDV, and 55 and $91 \%$ for LYSV. In the third, fourth, and fifth cycles, values were $100 \%$ for GYSV, 99 to $100 \%$ for OYDV, and 74 to $98 \%$ for LYSV. However, plants testing positive for GarVA ranged from $7.5 \%$ in the 1 st cycle to $18 \%$ in the 5 th cycle.

Analysis of the interaction between the categories of clove size planted (categories 2 and 3) and years of exposure to the virus (crop cycles) was not significant in any of the assays carried out. For this reason, analysis of the effect of number of years of exposure was based on the comparison of their mean values averaged over categories of clove size.

During the 5 years, each treatment planted virus-free (1st cycle) had a significantly higher yield than the other treatments (Table 2). In 1995, the 1st cycle plants produced bulbs of greater weight and perimeter than the 2nd cycle plants, and these were superior to the chronically diseased plants (VC plants) (Table 2). In 1996, a progressive reduction was seen again in yield in relation to the number of crop cycles the plant had been in the field. In 1997, significant differences between treatments, depending on years, were observed (Table 2). The 1st cycle treatment was significantly different from the rest. However, the 2nd, 3rd, and 4th cycle treatments were not different from each other, but were different from the $\mathrm{VC}$ treatment, which had the lowest values. In 
1998, highly significant differences between the crop cycles were detected (Table 2). The pair-wise analysis showed that three groups were different, with the 1 st and 2nd cycle garlic plants having highest values, the 3rd, 4th, and 5th cycle garlic with intermediate values, and the chronically diseased group having the lowest values.

Four categories of bulb size were defined using the 25, 50, and 75 percentiles (Table 3). The categories were "small", "medium-small", "medium-large", and

Table 2. Mean and standard error (SEM) for weight and perimeter of garlic bulbs for different crop cycles by year

\begin{tabular}{lllccc}
\hline & \multicolumn{2}{c}{ Bulb weight $(\mathbf{g})$} & & \multicolumn{2}{c}{ Bulb perimeter $(\mathbf{c m})$} \\
\cline { 2 - 3 } \cline { 5 - 6 } Treatments & Mean & SEM & & Mean & SEM \\
\hline 1st cycle 1994 & $39.3 \mathrm{a}^{\mathrm{y}}$ & 2.5 & & $15.1 \mathrm{a}$ & 0.3 \\
VC $^{\mathrm{z}}$ 1994 & $23.7 \mathrm{~b}$ & 0.8 & & $13.3 \mathrm{~b}$ & 0.2 \\
1st cycle 1995 & $91.9 \mathrm{a}$ & 5.2 & & $21.2 \mathrm{a}$ & 0.5 \\
2nd cycle 1995 & $78.5 \mathrm{~b}$ & 4.3 & & $19.9 \mathrm{~b}$ & 0.5 \\
VC 1995 & $46.2 \mathrm{c}$ & 2.2 & & $17.3 \mathrm{c}$ & 0.3 \\
1st cycle 1996 & $85.6 \mathrm{a}$ & 2.7 & & $19.8 \mathrm{a}$ & 0.3 \\
2nd cycle 1996 & $61.6 \mathrm{~b}$ & 1.8 & & $17.4 \mathrm{~b}$ & 0.2 \\
3rd cycle 1996 & $43.8 \mathrm{c}$ & 1.4 & & $15.5 \mathrm{c}$ & 0.2 \\
VC 1996 & $27.1 \mathrm{~d}$ & 0.9 & & $13.1 \mathrm{~d}$ & 0.1 \\
$1^{\circ}$ cycle 1997 & $53.2 \mathrm{a}$ & 1.6 & & $17.1 \mathrm{a}$ & 0.2 \\
$2^{\circ}$ cycle 1997 & $32.9 \mathrm{~b}$ & 0.9 & & $14.4 \mathrm{~b}$ & 0.1 \\
$3^{\circ}$ cycle 1997 & $34.7 \mathrm{~b}$ & 0.9 & & $14.7 \mathrm{~b}$ & 0.1 \\
$4^{\circ}$ cycle 1997 & $32.5 \mathrm{~b}$ & 0.8 & & $14.1 \mathrm{~b}$ & 0.1 \\
VC 1997 & $22.5 \mathrm{c}$ & 0.6 & & $12.5 \mathrm{c}$ & 0.1 \\
1st cycle 1998 & $75.7 \mathrm{a}$ & 1.8 & & $19.4 \mathrm{a}$ & 0.2 \\
2nd cycle 1998 & $67.5 \mathrm{~b}$ & 1.8 & & $18.9 \mathrm{a}$ & 0.2 \\
3rd cycle 1998 & $42.6 \mathrm{c}$ & 1.2 & & $16.0 \mathrm{~b}$ & 0.2 \\
4th cycle 1998 & $44.6 \mathrm{~cd}$ & 1.3 & & $16.0 \mathrm{~b}$ & 0.2 \\
5th cycle 1998 & $49.9 \mathrm{~d}$ & 1.3 & & $16.9 \mathrm{c}$ & 0.2 \\
VC 1998 & $33.4 \mathrm{e}$ & 0.9 & & $14.6 \mathrm{e}$ & 0.1 \\
\hline
\end{tabular}

${ }^{y}$ Values in the same column and in the same year followed by the same letter are not significantly different $(P<0.001)$.

${ }^{\mathrm{z}} \mathrm{VC}=$ plants with the viral complex. "large". The purpose of this was to visualize the relationship between frequency of the various bulb size categories and time of viral infection (Table 3 ). In this table, dependence can be seen between the frequency of bulbs found in each size category (small, medium-small, medium-large, and large bulbs) and the crop cycles assessed that year. In the 1 st cycle, for both weight and perimeter, high percentages of large bulbs were detected (between 74 and $38 \%$ ) and a small quantity of small bulbs (between 4 and 17\%). In the second year, a significant reduction was found in the percentage of large bulbs, varying between 50 and $20 \%$. In the 3rd, 4th, and 5th cycles, there was a uniform-like distribution of bulbs among the different categories. In the $\mathrm{VC}$ treatments, higher percentages of small bulbs were observed and very few or no large bulbs.

The weight and perimeter decline curves are shown in Figure 1. The average values indicate an increase in yield, with respect to $\mathrm{VC}$ plants, of between 66 and $216 \%$ in weight and between 13 and $51 \%$ in perimeter of bulbs in the 1 st cycle; between 46 and $127 \%$ in weight and 15 and $33 \%$ in perimeter in the second year; between 27 and $62 \%$ in weight and 10 and $18 \%$ in perimeter in the third year; between 33 and $44 \%$ in weight and 10 and $13 \%$ in perimeter in the fourth year; and $49 \%$ in weight and $16 \%$ in perimeter in the fifth year.

\section{DISCUSSION}

When GarV-A was analyzed, the lowest levels of virus incidence were detected, just $18 \%$ after 5 years of exposure to the source of inoculum. These results are similar to those obtained in Japan by Takaichi et al. (21). Using allexivirus-specific antiserum, they detected $10 \%$ infection in garlic after 5 years in the field near a production area, and between 0 and $16 \%$ after 3 years in fields isolated from commercial crops.

The higher percentages of GYSVinfected plants detected in our study may be explained because this antiserum detects a mixture of allexiviruses and not a single virus, as do the GarV-A antiserum and the primers used by Takaichi et al. (21). GYSV was obtained from a mixture of viruses (5); however, in previous work using this an-

Table 3. Frequency distribution $(\%)^{y}$ by garlic bulb size for different treatments, according to weight and perimeter (Perim.) variables, in each year of assay

\begin{tabular}{|c|c|c|c|c|c|c|c|c|}
\hline \multirow[b]{2}{*}{ Treatments } & \multicolumn{2}{|c|}{ Bulb-small } & \multicolumn{2}{|c|}{ Bulb-medium small } & \multicolumn{2}{|c|}{ Bulb-medium large } & \multicolumn{2}{|c|}{ Bulb-large } \\
\hline & Weight & Perim. & Weight & Perim. & Weight & Perim. & Weight & Perim. \\
\hline 1st cycle 1994 & 7 & 15 & 31 & 31 & 22 & 16 & 40 & 38 \\
\hline$V^{z} 1994$ & 31 & 30 & 24 & 24 & 30 & 28 & 15 & 18 \\
\hline 1st cycle 1995 & 15 & 17 & 10 & 15 & 25 & 20 & 50 & 48 \\
\hline 2nd cycle 1995 & 14 & 18 & 18 & 20 & 40 & 38 & 28 & 24 \\
\hline VC 1995 & 46 & 39 & 48 & 57 & 6 & 4 & 0 & 0 \\
\hline 1st cycle 1996 & 6 & 6 & 5 & 6 & 15 & 18 & 74 & 70 \\
\hline 2nd cycle 1996 & 11 & 10 & 17 & 28 & 34 & 29 & 38 & 33 \\
\hline 3rd cycle 1996 & 24 & 22 & 34 & 41 & 30 & 26 & 12 & 11 \\
\hline VC 1996 & 50 & 51 & 39 & 43 & 11 & 6 & 0 & 0 \\
\hline 1st cycle 1997 & 11 & 10 & 10 & 11 & 22 & 20 & 57 & 59 \\
\hline 2nd cycle 1997 & 19 & 18 & 29 & 30 & 32 & 31 & 20 & 21 \\
\hline 3rd cycle 1997 & 20 & 19 & 26 & 24 & 26 & 29 & 28 & 28 \\
\hline 4th cycle 1997 & 20 & 22 & 30 & 30 & 29 & 28 & 21 & 20 \\
\hline VC 1997 & 53 & 51 & 28 & 30 & 15 & 15 & 4 & 4 \\
\hline 1st cycle 1998 & 4 & 7 & 12 & 12 & 29 & 23 & 55 & 58 \\
\hline 2nd cycle 1998 & 8 & 7 & 14 & 16 & 32 & 27 & 46 & 50 \\
\hline 3rd cycle 1998 & 34 & 30 & 29 & 32 & 26 & 25 & 11 & 13 \\
\hline 4th cycle 1998 & 36 & 35 & 27 & 24 & 23 & 24 & 14 & 17 \\
\hline 5th cycle 1998 & 21 & 21 & 30 & 26 & 29 & 33 & 20 & 20 \\
\hline VC 1998 & 46 & 43 & 36 & 36 & 17 & 20 & 1 & 1 \\
\hline
\end{tabular}

y Percentages were calculated on the total of bulbs harvested for each treatment in each year of assay.

${ }^{\mathrm{z}} \mathrm{VC}=$ plants with the viral complex. 
tiserum, we did not detect either OYDV or LYSV, but obtained only strong positive response to plants infected with allexiviruses (V. C. Conci, unpublished results).

In our assays, LYSV infection was high in all the years analyzed (between 54 and $86 \%$ ) in the 1st cycle plants (Table 1). The source of inoculum was $60 \mathrm{~cm}$ away from the healthy plants, since one of the treatments in each assay was a chronically diseased plant. Takaichi et al. (21) detected $70 \%$ infection with LYSV in a field planted 5 years earlier near a commercial garlic crop, without any significant reduction in bulb yield. They argued that LYSV infection does not greatly affect the yield. At the same time, in two fields situated farther from garlic production areas, they detected $8.3 \%$ LYSV-infected plants after 3 years cultivation (21).

Carvalho et al. (5) observed during two consecutive years that the mean weight of bulbs of the California Early cultivar decreased $12.9 \%$ in the first year and $13.1 \%$ in the second year (not accumulative data) as a consequence of artificial infection with the mixture of viruses detected by the GYSV antiserum. Lot et al. (15), also observed greater losses in bulb weight when the plants had gone through more than one crop cycle of infection, with respect to recently infected plants, suggesting that yields were reduced more as more crop cycles pass in the field.

Our results obtained after 5 years of assays in the field show high percentages of plants are infected in the first cycle in the field and yield less in the following crop cycle. In any case, this decrease in yield would not economically justify their replacement with healthy "clove-seed" for planting, since these plants, with two cycles of infection, still have a much higher yield than plants with more cycles in the field and are clearly different from chroni- cally infected garlic, which gives less than half the yield.

Data analysis of weight and perimeter of garlic cloves established highly significant differences between the treatments according to years of exposure to infective conditions, indicating there is a progressive loss in yield until at least the third year. An exception occurred in the year 1997, where the 1st cycle plants were markedly different, the $2 \mathrm{nd}$, 3rd, and 4th cycles constituted an intermediate group, and the chronically diseased showed the lowest measures of weight and perimeter. One possibility for this is that, in addition to the length of time of the infection, there may be interactions between different viruses present in the garlic complex, as has been shown with synergistic effects between SLV, a carlavirus not evaluated in this study, and LYSV in leek plants (2). In addition, in the development of viral populations, the dynamics of generation or introduction of intraspecific variants in a new infection may be important. A healthy plant is a new environment to be colonized in which the dynamics of multiplying viral variants could play an important role in the yield. Finally, in 1998, the 2nd cycle plants were not significantly distanced from the 1 st cycle plants as in 1997, but those that had been 2nd cycle in 1997 and constituted 3rd cycle plants in 1998 showed poorer results than the 4th and 5th cycle plants, which shows that those plants had been dramatically affected during the 1997 cycle and had not recovered.

In the frequency distribution table (Table 3 ), it can be seen that the 1 st and 2 nd cycle treatments in the field produced mainly large bulbs and few small bulbs. With more than two cycles in the field, the plants produced bulbs distributed mainly in the central categories (medium-small and medium-large), with a high percentage of small bulbs. Finally, the VC plants produced few or no large bulbs, and most of the bulbs fitted into the small category in all years.

Plants in this assay were subjected to a high inoculum pressure (infected plants were cultivated next to healthy plants), which caused rapid viral infection. In a crop with less exposure to viruses, the yield loss would certainly be slower and so the plant replacement period could be extended.

The curves of weight and perimeter of bulbs harvested (Fig. 1) show a progressive decline in yield until the third crop year in the field. Then, there is a plateau that does not yet reach the levels of the chronically infected plants, but it is approximately $44 \%$ in weight and $13 \%$ in perimeter below the average of plants in their first year in the field. Farmers' experiences agree with our results. They have observed that after 5 years of cultivation in the field, yields are still higher than those of chronically infected plants.

From the results, it is apparent that a significant reduction in yield can be expected as the years of cultivation and exposure to viruses in the field pass. This suggests the periodic renewal of "seed cloves" with new virus-free material is required to maintain the profitability of the crop.

\section{ACKNOWLEDGMENTS}

We thank M. Carvalho, R. Shepherd, H. Lot, B. Delecolle, L. Bos, D. Maat, R. Milne, and E. Luisoni for providing the antisera that made this work possible. We thank Plantaflor S.A., who enabled us to carry out the assays made in Montecristo and Rio Primero in their farm fields, and also their kind collaboration in the development of the crop. This study was supported with funds from National Agricultural Technology Institute (INTA), National Council for Scientific and Technical Investigations (CONICET), Córdoba Science Agency, and National Agency for Promotion of Science and Technology (projects CABBIO and FONCyT).
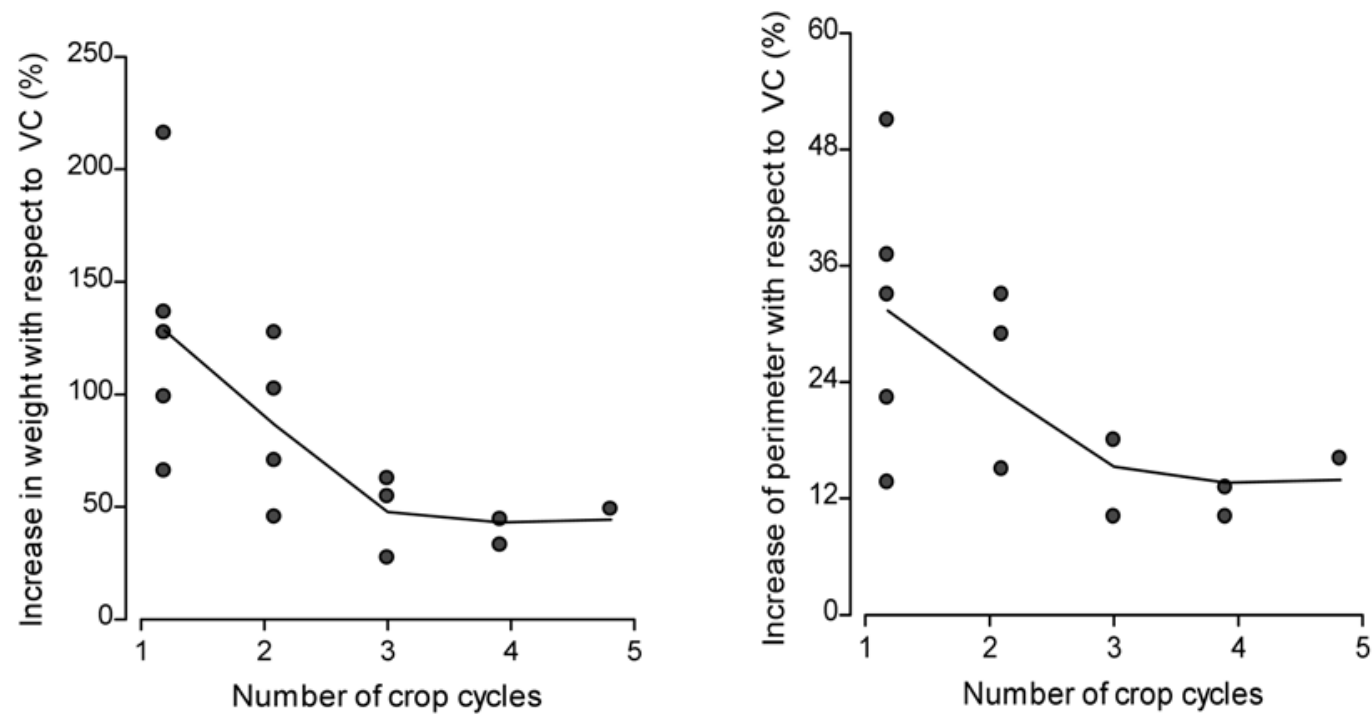

Fig. 1. Curves of reduction in average weight (left) and perimeter (right) of garlic bulbs against number of years of exposure to viral infection (crop cycles). $\mathrm{VC}=$ plants with viral complex. 


\section{LITERATURE CITED}

1. Barg, E., Lesemann, D. E., Vetten, H. J., and Green, S. K. 1994. Identification, partial characterization and distribution of viruses infecting Allium crops in south and southeast Asia. Acta Hortic. 358:251-258.

2. Bos, L. 1982. Viruses and virus diseases of Allium species. Research Institute for Plant Protection. Acta Hortic. 127:11-29.

3. Canavelli, A., Nome, S. F., and Conci, V. C. 1998. Efecto de distintos virus en la producción de ajo (Allium sativum) Rosado Paraguayo. Fitopatol. Bras. 23:354-358.

4. Carvalho, M. G. 1981. Viroses do alho. Fitopatol. Bras. 6:299-300.

5. Carvalho, M. G., Shepherd, R. R., and Hall, D. H. 1981. Virus em clone de alho sem sintomas e liberto do Garlic yellow stripe virus. Fitopatol. Bras. 6:236.

6. Chen, J., Chen, J. P., and Adams, M. J. 2002. Characterization of some carla- and potyviruses from bulb crops in China. Arch. Virol. 147:419-428

7. Clark, M. F., and Adams, A. N. 1977. Characteristics of the microplate method of enzyme linked immunosorbent assay (ELISA) for the detection of plant viruses. J. Gen. Virol. $34: 475-482$

8. Cleveland, W. S. 1979. Robust locally weighted regression and smoothing scatterplots. J. Am. Stat. Assoc. 74:829-836.

9. Conci, V. C. 1997. Virus y fitoplasmas de ajo. Pages 267-291 in: 50 temas sobre producción de ajo, vol. 3. J. L. Burba, ed. EEA-INTA La Consulta, Mendoza, Argentina.

10. Conci, V. C., Helguera, M., and Nome, S. F. 1999. Serological and biological comparison of onion yellow dwarf virus from onion and garlic in Argentina. Fitopatol. Bras. 24:73-75.

11. Conci, V. C., Lunello, P., Buraschi, D., Italia, R. R., and Nome, S. F. 2002. Variations of Leek yellow stripe virus concentration in garlic and its incidence in Argentina. Plant Dis. $86: 1085-1088$
12. Conci, V. C., and Nome, S. F. 1991. Virus free garlic (Allium sativum L.) plants obtained by thermotherapy and meristem tip culture. J. Phytopathol. 132:189-192.

13. Helguera, M., Bravo-Almonacid, F., Kobayashi, K., Rabinowicz, P. D., Conci, V., and Mentaberry, A. 1997. Immunological detection of a GarV-type virus in Argentina garlic cultivars. Plant Dis. 81:1005-1010.

14. Helguera, M., Lunello, P., Nome, C., and Conci, V. C. 1997. Advances in the purification of filamentous viruses from garlic and in antisera production. ISHS. Acta Hortic. 433:623-630.

15. Lot, H., Chovelon, V., Souche, S., and Delecolle, B. 1998. Effects of onion yellow dwarf and leek yellow stripe viruses on symptomatology and yield loss of three French garlic cultivars. Plant Dis. 82:1381-1385.

16. Lunello, P., Ducasse, D., Helguera, M., Nome, S. F., and Conci, V. C. 2002. An Argentinean isolate of Leek yellow stripe virus from leek can be transmitted to garlic. J. Plant Pathol. 84:11-17.

17. Milne, R. G., and Luisoni, E. 1977. Rapid immune electron microscopy of virus preparations. Pages 265-281 in: Methods in Virology, Vol. 6. K. Maramorosch and H. Koprowski, eds. Academic Press, New York.

18. Montgomery, D. C. 1991. Diseño y análisis de experimentos. Grupo Editorial Iberoamérica, S.A. Mexico.

19. Ravnikar, M., Plaper, I., Ucman, R., and Zel, J. 1994. Establishment of an efficient method for virus elimination in meristem cultures and regeneration of high quality plants. Pages 97102 in: Proc. IPBA, Rogla. December 5-7, 1994.

20. Sumi, S., Tsuneyoshi, T., and Furutani, H. 1993. Novel rod-shaped viruses isolated from garlic, Allium sativum, possessing a unique genome organisation. J. Gen. Virol. 74:18791885.

21. Takaichi, M., Yamamoto, M., Nagakubo, T., and Oeda, K. 1998. Four garlic viruses identified by reverse transcription-polymerase chain reaction and their regional distribution in northern Japan. Plant Dis. 82:694-698.

22. Tsuneyoshi, T., Matsumi, K. T., Deng, T. C. Sako, I., and Sumi, S. 1998. Differentiation of Allium carlaviruses isolated from different parts of the world based on the viral coat protein sequence. Arch. Virol. 143:1093-1107.

23. Tsuneyoshi, T., Matsumi, K. T., and Sumi, S. 1998. Nucleotide sequence analysis of virus isolates indicates the presence of three Potyvirus species in Allium plants. Arch. Virol 143:97-113.

24. Tsuneyoshi, T., and Sumi, S. 1996. Differentiation among garlic viruses in mixed infections based on RT-PCR procedures and direct tissue blotting immunoassays. Phytopathology 86:253-259.

25. Van Dijk, P. 1993. Carlavirus isolates from cultivated Allium species represent three viruses. Neth. J. Plant Pathol. 99:233-257.

26. Van Dijk, P. 1993. Survey and characterization of potyviruses and their strains of Allium species. Neth. J. Plant Pathol. 99. Suppl. 2:148.

27. Verbeek, M., Van Dijk, P., and Van Well, M A. 1995. Efficiency of eradication of four viruses from garlic (Allium sativum) by meritem-tip culture. Eur. J. Plant Pathol. 101:231 239.

28. Walkey, D. G. A. 1990. Virus Diseases. Pages 191-212 in: Onions and Allied Crops, vol. II H. D. Rabinowitch and J. L. Brewster, eds. CRC Press, Boca Raton, FL.

29. Walkey, D. G. A., and Antill, D. N. 1989. Agronomic evaluation of virus-free and virusinfected garlic (Allium sativum L.). J. Hortic Sci. 64:53-60.

30. Walkey, D. G. A., Webb, M. J. W., Bolland, C. J., and Miller, A. 1987. Production of virusfree garlic (Allium sativum L.) and shallot $(A$ ascalonicum L.) by meristem-tip culture. J. Hortic. Sci. 62:211-220. 